\title{
Research on Social Responsibility and Credit Risk Control of Financial Institutions from the Perspective of Supply - side Reform
}

\author{
Gong Chao \\ Jilin business and technology college , NO.1666 Kalunhu Str. Changchun Jiutai economic \\ development zone. Changchun City, JiLin PROV. China, 130507 \\ cmz2997@sian.com
}

Keywords: Social Responsibility, Credit Risk, Financial Institutions

\begin{abstract}
In the face of the economy into the new normal, slow growth situation, exports, investment, consumption as Chinese economic development, "troika" demand-pull model has been unable to continue. This shows that Chinese economic problems are no longer short-term, cyclical demand stimulus, but long-term, structural supply pull problem. While promoting the reform in various fields, it should also carry out the structural reform of the supply side, rationally allocate the elements, expand the effective supply, and better meet the market demand and bear more social responsibility. Credit risk is one of the most important risks faced by current financial institutions. The level of management is not only affecting the bank's own business results, but also the internal risks of systemic financial risks. Therefore, financial institutions must strengthen credit risk management and improve credit risk prevention.
\end{abstract}

\section{Introduction}

Credit risk is one of the factors that financial institutions must take into account in measuring investment efficiency and profitability. After the economy enters the new norm, the credit risk of financial institutions is increasing. Financial institutions are increasingly faced with rising interest rate fluctuations, increased competition in the same industry, profitability slowdown in the operating environment, especially by the economic downturn and market liquidity dual pressures, non-performing loan rates continue to rise. Reinhart and Rogo-ff, Kindleberger and others believe that excessive debt is easy to induce systemic risk, leading to a banking crisis. It is the key to realize the transformation of its own transformation on how to adjust the credit management strategy on the basis of stable asset quality in the process of supply-side reform and domestic interest rate marketization. To improve the current state of the study to be clear: the supply side of the nature of structural reform is what? How can financial institutions allocate social responsibility so that the allocation of financial resources can be realized effectively? How to manage credit risk through social responsibility behavior management and legal mechanisms? This paper aims to change the existing research approach, from the reality of the policy and the implementation of the supply side of the reform practice, re-interpretation of the consolidation and the supply side of the reform of financial institutions under the social responsibility and credit risk management path, put forward more realistic improvement program.

\section{Analysis on Social Responsibility and Credit Risk Control}

In fact, credit is used to fulfill its commitment to long-term formation of trust and integrity. Broad credit, penetrate all aspects of credit relations, not only includes the credit system as the core of credit research, credit management and credit system, but also includes social life in the code of credit ethics. We can explore the credit from a different perspective. From the ethical and moral point of view to make social life and economic activities in harmony and orderly, the individual in 
society must be honest and trustworthy code of conduct as the basis, strictly fulfill their commitments to keep the promise of good quality. From a legal point of view, if the contract stipulates that the rights and obligations of both parties have a time difference, rather than immediate delivery, and both parties agree on each other's rights and obligations, this time that there is credit between the two sides. This article focuses on the meaning of credit at the economic level. From an economic point of view, credit is the user's right to use credit resources. The use of resources on the premise that the commitment to fulfill some of the value of the use of resources to match the right to use the right is actually a loan relationship, Chinese market economy continues to develop, the credit form is also rich. The original goods, money and credit as the credit function of the deepening, and constantly evolving to modern credit. According to the different market participants, credit can be divided into four types: corporate credit. Due to the role of the market, business owners, investors, creditors, debtors and other stakeholders must form a credit relationship between. The power of the debtor to obtain the deferred payment from the creditor in the economic activity is the result of short-term financing behavior, which forms the indirect credit of the enterprise. In addition, between the enterprise and its employees there is a credit relationship formed by the internal labor process.

Financial institutions in a variety of forms include financial institutions to loans, discounts, etc. to provide monetary form of credit. For example, according to different loan terms and other additional conditions, banks can provide different loans. In addition, financial institutions to provide credit participants are more complex. For example, banks are required to comply with their credit to depositors when they accept deposits, which are the main source of funds provided by banks to other participants. Therefore, the credit provided by the bank is based on the credit of the depositor. The government through the public recruitment, through the stock exchange or direct payment to the form of debtor to the identity of the people to borrow to make up for the lack of fiscal revenue, the formation of government credit. The treasury market, which is derived from it, is an important part of the financial system. Consumer credit refers to the consumer because of the needs of consumption, access to banks and enterprises and other subjects to provide the credit, that is, the main body of credit, so the use of funds or goods in the form of consumer credit.

Financial institutions as a provider of financial resources, in the supply side of the structural reform of the key role in the weakening of high consumption, high pollution, high input, low output industry financing requirements, and gradually transferred to high efficiency, high power, green of the strategic emerging industries to optimize the financial resources to promote the national level of supply side of the smooth implementation of reform. The traditional profit model of financial institutions has been unable to maintain its continued progress, and the supply side of the structural reform put forward, is to promote the arrival of financial institutions in the spring. Financial institutions, represented by commercial banks, should promptly develop new products, transfer the risks brought by non-performing assets, divide customers into differentiated and centralized financial resources in high-quality enterprises and industries.

The social responsibility of financial institutions is to put the financial resources owned by it to the most needed, the most environmentally friendly and optimized industries, to support the national energy conservation, high efficiency, environmental macroeconomic situation, and constantly promote the optimal allocation of resources. Through the analysis of national policies and contact the actual situation of the local community, a clear financial institution of social responsibility, and local conditions to the responsibility to implement, can really promote the supply side of the reform.

Financial institutions should be in the value chain stakeholders responsible for the obligation to carry out a profit space, the market potential of full financial business, in order to achieve the goal of capital preservation and appreciation. On the one hand, shareholders, creditors to invest capital in order to obtain value-added profits, on the other hand, consumers eager to obtain high-quality financial products, financial resources, which are financial institutions put forward the requirements of social responsibility. To large-scale, centralized performance characteristics of the bank resource supply structure and miniaturization, decentralized private economy there has been a serious match 
does not seriously hinder the economic quality and efficiency play. The fundamental problems of small business loans have not been resolved, the frequent problems of financial products, etc., require financial institutions from the perspective of stakeholders, as much as possible to fulfill more social responsibility to address the urgent financial problems, change the traditional profit mode to achieve capital preservation and appreciation.

Government and society as a financial institution of the value chain of external stakeholders, the same performance of its social responsibility has a high demand, strict standards. In the acquisition of potential value-added space at the same time, but also implement the country's macroeconomic policies to meet the community's environmental protection requirements. But the financial institutions in this area is not enough, emerging business opportunities are still very few, while large state-owned enterprises to support the economic constraints of the financial institutions of the transfer of resources, so the financial institutions of external interests related to social responsibility Only stay in the initial stage, still need to continue to advance. Financial institutions of the customer's high-quality polarization, leading to financial resources concentrated in the hands of a small number of large state-owned enterprises, and these state-owned enterprises from a relatively high credit risk, from the overall increase in the risk level. Strategic emerging industries, although late, but the potential, large profit margins, financial institutions should be transferred to more resources to support the development of small businesses, thereby reducing the state-owned enterprises and pulled higher credit risk.

Financial institutions for the state-owned enterprises to relax the credit regulation, will inevitably lead to some people will choose "free rider" in the credit resources "hands and feet", this result is bound to increase the credit risk. While the strict supervision of small businesses, lending approval requirements, resulting in resources can not be a reasonable allocation. Financial institutions credit risk can not form a perfect assessment system, supervision and coordination, is the largest adjustment task.

Financial institutions in the implementation of social responsibility at the same time will gradually reduce the credit risk, risk reduction, financial institutions can put more financial resources, which will assume more social responsibility, the formation of cross-period impact of the situation. But in which the key link must be strictly regulated, so as not to cause enterprises to "ride", and then cheat financial resources, resulting in increased risk.

\section{Suggestions on Credit Risk of Financial Institutions}

From the perspective of the value chain stakeholders, the implementation of social responsibility and the performance of financial institutions linked to the real social responsibility embedded in the profit model of financial institutions in order to make better use of financial resources, the most needed industry in. On the one hand, the need for the introduction of appropriate national policy documents to restrict the implementation of social responsibility of financial institutions, so that it really pay attention to it. On the other hand, within the financial institutions, improve the physical mechanism and the connotation of social responsibility into them making the financial business at the same time, from the side disguised the implementation of social responsibility.

"Zombie enterprises" serious losses, the direct consequence of the financial institutions can not be returned to the credit, indirectly hinder the rational use of financial resources. Faced with this situation, financial institutions must make corresponding changes, the appropriate choice of investment objects, to optimize the resource-oriented to control the credit risk for the protection. The establishment of a sound credit risk assessment system, not only from the customer choice, to give a more clear level of risk positioning, in the money on the way, you can also further track the flow of funds and potential returns, and then timely feedback, so that credit risk can be controlled in a reasonable range.

Under the structural reform of the supply side, the financial institutions must link the social responsibility performance and the credit risk together, and pay attention to the linkage effect of the two as a whole. Financial institutions to fulfill their social responsibilities can reduce the credit risk, will increase the credit risk, only properly handle the linkage between the two and strengthen 
supervision, in order to help financial institutions to smooth the supply side of the structural reform.

\section{Conclusion}

According to the law, set the credit disciplinary mechanism to help eliminate the commercial fraud and most other bad business practices, to a certain extent, to protect the credit economy. To this end, China should also build a credit regulatory platform, the establishment of financial credit incentives and disciplinary mechanisms. Second, from the social level, strengthen social moral construction, in the community to form a new credit fashion. Ethics is the foundation of credit construction. In the era of credit economy, credit becomes an important factor in resource allocation. Social moral construction mainly includes civic moral construction and professional ethics construction. Finally, from the enterprise level, to improve corporate social responsibility and credit awareness, the establishment of corporate credit system. Corporate social responsibility is the specific form of corporate credit, enhance corporate social responsibility awareness is conducive to improving financial credit, reduce financial credit risk. Strengthen the sense of social responsibility and credit consciousness can not be separated from the credit system construction. Corporate credit construction as part of the corporate strategy needs to be regulated by rules and regulations.

\section{References}

[1] An Ling, Huang Yinfeng. Study on the Change Motivation of Annual Publication of Listed Companies in China [J].Journal of Chongqing University of Technology. 2016 (06)

[2] Cao Haimin, Chang Yue. Analysis of the effect of enterprise financial credit evaluation on growth[J] .Environmental Issues. 2015 (10)

[3] Wang Xueqing, Chen Yangyang, Chen Weiwei. Study on decision-making mechanism of credit behavior of qualified personnel in construction market based on SD [J].Journal of Engineering Management. 2015 (01)

[4] Cao Haimin, Chu Liqin. Enterprise performance, financial credit and social responsibility[J]. Finance and Accounting. 2014 (06)

[5] Yan Yanyang, Liu Pengfei. Study on the Impact of Corporate Social Responsibility on Its Credit Risk [J]. Huxiang Forum. 2014 (01)

[6] Ao Hua, Zhao Xian. Chinese social credit management industry, the overall characteristics of the main problems and countermeasures[J]. Journal of Zhejiang Gongshang University. 2011 (01) 